\title{
Cancer Survivor
}

National Cancer Institute

\section{Source}

National Cancer Institute. Cancer Survivor. NCI Thesaurus. Code C18673.

An individual who has survived a cancer, and is in a disease free, chronic, or relatively stable stage. 